\title{
PRELIMINARY RESULTS OF MAPPING IN THE CRYSTALLINE COMPLEX AROUND NORDVESTFJORD, SCORESBY SUND, EAST GREENLAND
}

\author{
Niels Henriksen and A. K. Higgins
}

\author{
Introduction
}

The crystalline complex which outcrops around the inner part of Nordvestfjord to the south of latitude $72^{\circ} \mathrm{N}$, and around the Bjфrneфer situated at the entrance to Nordvestfjord, was mapped by GGU in the summer of 1968 at a scale of 1:50000. The following geologists participated in the mapping project (areas mapped by each geologist are given in brackets): J.D. Friderichsen, Copenhagen (SW Hinks Land and south of Flyverfjord); N. Henriksen, Copenhagen (valleys west and south of Flyverfjord and a zone of the western nunataks); A.K. Higgins, Copenhagen (as N. Henriksen); F. Kalsbeek, Aarhus (Bjørneфer and surroundings); F. Keller, Basle (NE of Nordvestfjord); E. Kirsbo, Copenhagen (NE Hinks Land) and A. Steck, Basle (NW Hinks Land and Charcot Land). The preliminary results of the mapping are presented in this paper together with a geological map on a scale of 1:500000. In the coming years most of the participants will publish detailed accounts of their individual areas and geological map sheets on a scale of 1:100000 will be published by GGU.

The mapping was a team project and in preparing this paper the authors have drawn widely from ideas and views expressed by the other participants in discussions, in preliminary reports, and on field maps. The authors acknowledge their gratitude and indebtedness to the other members of the team but this does not imply that all members accept the interpretations the authors have based on their results.

The only significant geological investigations undertaken within the mapped area prior to the current work have been the reconnaissance work by Backlund, Wenk and others in 1934 (Backlund, 1955), several extended traverses by Wenk during the 1950's and the work by Vogt in 1958 (Wenk, 1956; Vogt, 1965). 
The crystalline complex

The mapping of the area around inner Nordvestfjord has revealed the existence of two distinct sequences of supracrustal rocks. The easternmost of these has been termed informally the Krummedal supracrustal sequence and that to the west the Charcot Land supracrustal sequence. Each supracrustal sequence is underlain by a different and distinctive complex of infracrustal rocks.

The Krummedal sequence and its infracrustal complex are separated from the Charcot Land sequence and its infracrustal complex by a major thrust plane, the Hinks Land overthrust. The Krummedal sequence has been thrust westwards over the Charcot Land sequence.

Previous workers in the region have interpreted the two supracrustal sequences as representing different levels in the same series (Wenk, 1961; Vogt, 1965). However, as non-tectonic contacts between the two sequences are unknown they are regarded as separate, and described independently in this paper. Their possible relative ages are discussed subsequently.

The Charcot Land supracrustal sequence

Supracrustal rocks of the Charcot Land sequence outcrop in southern Charcot Land along the north side of Daugaard-Jensen Gletscher, are found on the south side of the same glacier in north-west Hinks Land and continue into the western nunataks of the area to the south.

The Charcot Land sequence comprises marbles, siliceous marbles, quartzites, semipelites, pelites, greenschists and a number of basic to intermediate lensoid intrusions. The greenschists, which form extensive sequences in some areas, are generally homogeneous and fine-grained but locally preserve pillow structures which testify to an effusive subaqueous origin for at least parts of these sequences. The lensoid intrusions are generally conformable to the surrounding metavolcanics and metasediments; where they border bands of carbonates contact metamorphic alterations are frequently conspicuous. 
The Charcot Land sequence exhibits a varying degree of regional metamorphism. The lowest grade rocks representing greenschist facies conditions are preserved in the south-western outcrops and the grade progressively increases towards the north-east reaching amphibolite facies near the front of Daugaard-Jensen Gletscher. As the metamorphic grade varies, greenschists alter to amphibolites, fine-grained chlorite-bearing semipelites pass into kyanite-garnet-biotite schists, and talc and tremolite appear in the carbonates.

The amphibolite and marble horizons in the gneisses on the north side of Nordvestfjord opposite Charcot Land may represent highly metamorphosed remnants of the Charcot Land sequence.

The infracrustal complex of Charcot Land

Much of Charcot Land comprises infracrustal rocks. In the east homogeneous, foliated, biotite augen gneisses underlie the Charcot Land sequence. Towards the north-west there appears to be a gradual transition into banded gneisses with extensive rusty-weathering amphibolite horizons. Thick zones of quartzitic gneiss are encountered in north-west Charcot Land. The relationships between the different gneiss types are uncertain because outcrop is discontinuous due to a large part of the area comprising nunataks and to the presence of later extensive granitic bodies.

It is likely, although it cannot be proved, that the infracrustal gneisses of Charcot Land represent the remnants of a basement to the Charcot Land series. Subsequent reactivation and the folding together of supracrustals and infracrustals has obliterated any evidence of an original disconformity and resulted in a conformable structural pattern.

The progressive metamorphism affecting the Charcot Land supracrustal sequence appears to coincide with a transition in the infracrustals between a homogeneous medium-grained granite and augen gneisses; the granite veins the Charcot Land sequence in western Charcot Land. It may be that this granite was originally much more extensive and that the augen gneisses were derived from it during progressive metamorphism and reactivation. However, it is also possible that the granite postdates the 
augen gneisses and was emplaced in such a way that it veined the Charcot Land sequence to which it has sharp boundaries, but exhibited more transitional boundaries to the infracrustals.

The granite is very homogeneous, sometimes foliated, and only locally along the east border of the main outcrop have inclusions of amphibolite and gneiss been observed. It would appear that the granite was emplaced under fairly static conditions, and if the veining of the granite into the folded Charcot Land sequence is original and not a feature of secondary reactivation it must be late-kinematic and probably also latemetamorphic.

The prominent allochthonous granite in northern Charcot Land is described in a later section.

A tillite and the age of the Charcot Land sequence

A small occurrence of a spectacular tillite about 0.5 by $1.5 \mathrm{~km}$ in outcrop area rests with angular unconformity on the granite in western Charcot Land *. The tillite is consolidated and the original transgressional surface is steeply inclined. Minor folds are inconspicuous but a shearcleavage is often visible and locally pronounced.

The tillite is several hundred metres thick and overlain conformably by a grey arkose. The groundmass of the tillite is a blackish, banded, arenaceous-arkosic rock with abundant semipelitic and pelitic layers. Repetitive graded bedding reminiscent of varves is not uncommon. The components in the tillite vary in size from rock fragments a few millimetres across to boulders up to 2 metres in diameter. Many of them are rounded or have rounded edges. The rock types present in the boulders appear to be largely of local derivation. Most of them are similar to the underlying granite and to the gneisses below the Charcot Land sequence, but many of the supracrustal rocks of the Charcot Land sequence are represented as pebbles or boulders.

* The age of this spectacular tillite and its occurrence will be described and discussed further by its discoverer A. Steck in a coming paper. 
Tillites of an Eocambrian age are known from several localities in East Greenland, among others from the region north of Scoresby Sund where they occur in a narrow belt in areas of supracrustal rocks folded during the Caledonian orogeny (Frankl, 1953; Katz, 1954). The closest locality lies about $180 \mathrm{~km}$ ENE of the Charcot Land tillite. A tillite of earlier age has been described by Wenk (1961) from Gaaseland, about $180-200 \mathrm{~km}$ south of Charcot Land, resting directly on an infracrustal basement and conformably overlain by a Precambrian marble-chloritephyllite series. At the present stage of investigation it is not possible with certainty to correlate the Charcot Land tillite with either of these tillites. While stratigraphical and structural considerations imply an Eocambrian age there are striking petrological similiarities with the Gaaseland tillite.

The Hinks Land overthrust

The trace of the Hinks Land overthrust may be followed along the north-west margin of Hinks Land and southwards through a group of nunataks to the margin of the mapped area. The overthrust may be a single plane or several related thrust planes. Throughout its outcrop the overthrust dips east or south-east at gentle angles.

Above and east of the thrust plane occur the supracrustal rocks of the Krummedal sequence, which in Hinks Land, on both sides of Flyverfjord and in the areas to the south and west, rest on a complex of infracrustal rocks. The excellent exposures of the infracrustals in the steep walls of Flyverfjord have led to the informal designation of this fairly extensive area of infracrustals as the Flyverfjord infracrustal complex.

In the nunataks along the extreme west margin of Charcot Land the Krummedal sequence again outcrops and is separated from the distinctive rocks of Charcot Land already described by a major thrust plane dipping gently to the west. The thrust may be a continuation of the Hinks Land overthrust or be a related thrust plane of probably similar age. The occurrence of undoubted Krummedal sequence rocks in this area gives some idea of the magnitude of the movements on the thrusts; there must have been an overall westward displacement of more than $40 \mathrm{~km}$. 
The Flyverfjord infracrustal complex

The rocks of the Flyverfjord infracrustal complex outcrop over extensive areas around inner Nordvestfjord. The Krummedal sequence dips off the infracrustals to the west, south and east and forms a partial cap to the complex in Hinks Land. These infracrustal rocks suffered metamorphism and deformation prior to the deposition of the Krummedal sequence and both units have been subjected subsequently to further folding and metamorphism which produced the present apparently conformable boundary between the two units.

A considerable variety of rock types make up the Flyverfjord infracrustal complex. Light-grey banded to veined gneisses characterised by abundant conformable amphibolite bands and lenses are common. While most gneisses contain biotite, more mafic types are hornblende-bearing. Homogeneous to nebulitic gneisses occur as zones especially in the Flyverfjord area. There are many amphibolite bands of which a large proportion contain ultrabasic lenses. Ultrabasic lenses and bodies also occur independently and may be quite extensive; examples over $1 \mathrm{~km}$ long and more than several hundred metres in width have been mapped; hornblendite, dunite and peridotite rock types dominate. Ultrabasics appear to be restricted, in the region mapped, to the Flyverfjord infracrustal complex.

Amphibolite bands are abundant and persistent in Hinks Land and south of Flyverfjord where their use as marker horizons has led to the elucidation of complex double-folding patterns.

On the north side of Nordvestijord amphibolites are perhaps slightly less abundant than on the south side but the main structural elements are clear. A pink gneissic granite containing numerous thin partly digested amphibolite bands forms here a minor domal structure cut by the north wall of Nordvestfjord. The dome is outlined by a continuous amphibolite horizon with a number of associated marble lenses.

In some parts of the infracrustal complex mica schist bands are sufficiently persistent to be useful as marker horizons.

Pegmatites are locally abundant, often folded and of at least two generations. 
A conspicuous feature of the Flyverfjord infracrustal complex in many areas are swarms of folded, discordant, amphibolite dykes. They postdate at least one period of deformation and plutonism which formed the gneissic complex, and have subsequently suffered a further period of deformation and plutonism which partly reactivated the already folded gneisses. The dykes are usually 5 to $10 \mathrm{~m}$ wide but may reach $50 \mathrm{~m}$ occasionally. Intrusive and textual features such as en echelon structures, chilled margins and phenocrysts are not uncommon, the degree of preservation depending upon the intensity of deformation. While the dykes occur throughout the complex their abundance varies; up to a hundred dykes may be visible in some areas whereas a few scattered dykes are present in others.

The Krummedal supracrustal sequence

The main outcrops of the Krummedal supracrustal sequence surround and cap the Flyverfjord infracrustal complex. Some of the thickest and most spectacular sections of the sequence are found in Krummedal, west of Flyverfjord, from which the sequence derives its name. The Hinks Land overthrust limits the main outcrops of the sequence to the west, but further outcrops of the Krummedal sequence are found in the outermost nunataks of Charcot Land where they are brought down by the westward continuation of the Hinks Land overthrust, or a related thrust.

The Krummedal sequence is generally well exposed but the intensity of deformation hinders the establishment of a detailed lithological succession. At the present stage of investigation it is convenient to divide the Krummedal sequence into a lower and upper part.

1. The lower part of the Krummedal sequence

The best exposures of this part of the sequence are found in the upper sections of the deeply incised valleys west of the head of Flyverfjord. Further outcrops are found in Hinks Land where it occurs as a thin zone 
between the infracrustals and the upper part of the Krummedal sequence, and it may be present as a thin wedge in a corresponding structural position north of Nordvestfjord.

In the two valleys west of Flyverfjord the lower part of the sequence outcrops in simple domal structures, in each case truncated to the west by a fault. The relative simplicity of the structures here permits estimates of the thickness of the series as of the order of at least $1000 \mathrm{~m}$. The series comprises a sequence of homogeneous and banded greenish-grey siliceous gneisses with thin layers of quartzites, schists and talc-rocks locally, into which abundant basic sills have been intruded. The gneisses are rich in chlorite and epidote and the sills are fine-grained greenstones. Occasional cross-cutting greenstone sheets and dykes appear to be related to the sills.

In Hinks Land and around the head of Flyverfjord deformation has been intense and estimates of thickness are of dubious value. The sequence can, however, be traced continuously as a unit. In this area it comprises light coloured banded paragneisses with abundant siliceous gneiss and quartzite bands, and, as elsewhere, numerous basic sills.

The lower boundary of the lower Krummedal sequence is poorly defined in many areas because of the apparent conformity between the sequence and the infracrustals below, and lithological similarities between banded infracrustal gneisses and the paragneisses of the lower Krummedal sequence. In some places a thin amphibolite in the infracrustal complex parallels the boundary for some distance and has been used as a convinient marker band and a boundary to the sequence.

The mutual boundary between the lower and upper parts of the Krummedal sequence is usually conspicuous due to the strong colour contrast between the grey rocks of the lower Krummedal sequence and the reddish-brown strata of the upper Krummedal sequence. A further conspicuous feature locally is a distinct marble horizon often $50 \mathrm{~m}$, but up to $150 \mathrm{~m}$, thick usually associated with a thin amphibolite; where present they are considered as the uppermost horizons of the lower part of the Krummedal sequence. 
2. The upper part of the Krummedal sequence

The upper Krummedal sequence comprises banded metasediments of pelitic and arenaceous origin usually red-brown in colour and several thousand metres thick; the upper limit of the sequence has not been observed. The lithological development varies from one part of the area to another indicating lateral variations in facies.

The valleys west of Flyverfjord exhibit thick monotonous successions of interbanded pelitic and quartzitic rocks. In places the quartzite bands contain thin carbonate lenses. The bands may be from a few centimetres to several metres in thickness. The outcrops of this sequence in the nunataks of western Charcot Land have a very similar development.

In Hinks Land in the outcrops west and south of Flyverfjord the upper Krummedal sequence has generally a more massive aspect, although south of Flyverfjord thick pale grey schistose zones in the sequence are conspicuous for their ease of weathering. The massive rocks are mainly coarse, banded kyanite-garnet-mica schists; thick quartz-rich zones are also abundant and calc-silicate lenses occur occasionally.

In many areas the normal facies of the upper Krummedal sequence grades upwards into more siliceous rocks; quartzites, micaceous quartzites, and banded quartzites with sillimite-garnet-biotite gneiss zones have been noted.

The grade of metamorphism of the Krummedal sequence seems fairly constant over the whole area. Garnet-rich rocks with abundant kyanite or silliminite are seen nearly everywhere, and even in the valleys west of Flyverfjord where the primary sedimentary character of the rocks is most apparent and the grade appears to be lower than elsewhere biotite and garnet are not uncommon.

Basic sills (and dykes) of the type apparent in the lower part of the Krummedal sequence are not seen in the upper part of the sequence. 
Migmatites and autochthonous-parautochthonous granites

As the supracrustals of the Krummedal sequence are traced eastwards along Nordvestfjord they pass into migmatites; migmatites and granites outcrop in the walls of the entire outer part of Nordvestfjord and as far as Bjфrneфer. It is of considerable interest that in both the nunataks north of Krummedal and in the westernmost nunataks of Charcot Land the upper Krummedal sequence also passes into migmatitic rocks, and in each of these areas the change takes place as the succession is traced upwards.

In Nordvestfjord the neosome of the migmatites is a homogeneous, grey fine-grained granite, and the paleosome comprises banded garnet gneisses and quartzites. The quartzites survive in the paleosome in nearly all degrees of migmatisation. The similarity of the rocks of the paleosome to those of the Krummedal sequence suggests that a large part of the migmatites were derived from the rocks of this sequence; the granitic neosome is considered to have permeated and partly digested the original supracrustals.

In the two nunatak areas the migmatitic appearence is due to the formation of feldspar augen in the metasediments and to the development of a gneissic character, as well as the emplacement of numerous semiconcordant granite sheets.

Synkinematic garnetiferous augen granites are conspicuous in parts of Nordvestfjord. They have a sheet-like form but may be more than a thousand metres thick; they may be foliated or gneissic and may have sharp or gradational boundaries with the surrounding migmatites. In some places the margins of the granites appear to be folded with the migmatites.

The Bjфrneфer comprise almost entirely migmatites and granites with locally well preserved metasediments including marbles. Detailed mapping has revealed three granite generations, of which the two older are synmigmatitic, one of them forming the neosome to the migmatites; the youngest, usually occurring as dykes, is clearly post-migmatitic. Intermediate to basic intrusives appear to be related to an early stage of migmatisation. 
In Hinks Land a number of synkinematic autochthonous granite bodies occur in a structural position between the infracrustal complex and the lower part of the Krummedal sequence. The granites are foliated biotite granites or granitic gneisses and the structures in them are conformable to the surroundings. They contain abundant relics of mafic bands which suggests they are replacive granites. Pegmatites several hundred metres thick and traceable for several kilometres appear to be related to these granites. Later aplites and pegmatites cut both the infracrustal complex and the autochthonous granites and are unfolded. A network of very coarse-grained late pegmatites is widespread in the vicinity of the mouth of Flyverfjord.

\section{Structures}

It is evident that the structural history of the Nordvestfjord region is very complex and detailed local chronologies have been established. A comprehensive review of the sequence of deformation is not possible at the present stage of research but general structural trends are emerging in different parts of the region.

The infracrustal complex of Charcot Land and the Flyverfjord infracrustal complex both suffered deformation prior to the deposition upon them of their respective supracrustal sequences. In Hinks Land a major fold phase produced recumbent structures with amplitudes of up to $5 \mathrm{~km}$ in some areas and there is evidence for earlier isoclinal folding in the occurrence of minor intrafolial folds. Superimposed on these early structures are several major phases of folding which deform both supracrustals and infracrustals.

At least two major fold phases are represented in the Krummedal sequence of Hinks Land and the areas south and west of Flyverfjord. The earlier phase produced tight folding over a large area, and a zone of particularly intense tight to isoclinal folding may be traced across the head of Flyverfjord in a NNE-SSW direction. In Hinks Land where the later fold phase is pronounced the early phase is seen only as minor folds. 
The second main fold phase affecting the Krummedal sequence is most pronounced in Hinks Land where a number of major structures with steep axial planes and amplitudes of several kilometres have been mapped; these structures trend N-S to NNE-SSW. Major folds of this phase are not conspicuous west or south of Flyverfjord but minor folds with a similar trend have been recorded. South of Flyverfjord several late major structures with ENE-WSW trends have been observed, but it is uncertain at present whether they represent a new fold trend, or merely a swing in trend of the second fold phase.

In the Charcot Land sequence an early phase of folding took place along $\mathrm{E}-\mathrm{W}$ to $\mathrm{SE}-\mathrm{NW}$ axes giving rise in places to intense folding. A second fold phase is represented by open $\mathrm{N}-\mathrm{S}$ folds which probably developed subsequent to the intrusion of a late- to post-kinematic granite in Charcot Land which is described in a separate section (see p. 17).

While the structural trends of the second folds in the Charcot Land sequence are similar to those of the second folds in the Krummedal sequence there are differences in style and intensity of deformation. Furthermore, the Hinks Land overthrust appears in places to cut obliquely through structures in both supracrustal sequences indicating that it postdates them and implying that the areas in which the two sequences occur were once considerably more distant from each other than they appear at present. It cannot be assumed that the folding in the Charcot Land sequence and that in the Krummedal sequence developed during the same epoch.

The tillite in western Charcot Land occurs structurally below the continuation of the Hinks Land overthrust, or a related thrust, and whether the tillite is regarded as Eocambrian or earlier the thrusting is very probably of Caledonian origin.

The passage of the Krummedal sequence upwards into migmatites in the nunatak areas west of Flyverfjord and in extreme west Charcot Land, areas which structurally overlie the Hinks Land overthrust, may indicate that migmatisation was here initiated from the infracrustal core of a nappe. Wenk (1961) explained an upwards increase in metamorphic grade in Gaaseland supracrustal rocks in a similar way. 
Allochthonous granites

In Charcot Land a very coarse-grained to pegmatitic, leucocratic, muscovite granite outcrops over an area of about $25 \mathrm{~km}$ by $10 \mathrm{~km}$. A marginal zone of the body some kilometres in width consists of a permeating network of pegmatitic veins and dykes whose proportion relative to the country rock inclusions increases towards the centre of the granite body. The marginal zone cuts members of the Charcot Land sequence, the adjacent augen gneisses and banded gneisses, and in northern Charcot Land banded gneisses with garnet amphibolite bands. The inclusions of the various types of country rock in the marginal zone are often non-rotated implying that the mis-en-place of the granite is here partially replacive. Local detailed studies indicate that there are a number of successive granite phases of similar composition but varying grain-size rather than a single intrusive phase.

The granite is clearly later than the main deformation of the surrounding rocks, and from this point of view is post-kinematic. However, it is slightly affected by the late open N-S folding with respect to which it is late-kinematic.

$$
\text { Post-kinematic basic dykes }
$$

A swarm of approximately $\mathrm{N}-\mathrm{S}$-trending dolerites of a probable Tertiary age cuts the crystalline rocks in the area around inner Nordvestfjord; they have not been observed in the central and outer part of the fjord region. Individual dykes vary from 5 to $40 \mathrm{~m}$ in thickness but most measure 10 to $20 \mathrm{~m}$. Some dykes are locally irregular where they have been diverted along pre-existing lines of weakness, and some are discontinuous. 
The upper part of the Krummedal supracrustal sequence has strong similarities lithologically with the deeper parts of the Caledonian geosynclinal sequence as described from the region between Kejser Franz Josephs fjord and Alpefjord (Alpefjord Series + Eremitdal Series of Fränkl (1953); Arenaceous-argillaceous Series to Argillaceous-arenaceous Series of Haller and Kulp (1962); Alpefjord Formation of Katz (1961)). In total these deeper parts of the Caledonian sequence are more than $6600 \mathrm{~m}$ thick. Correlation between the Krummedal sequence and the sequence described from Alpefjord is supported by the fact that the outcrop of the Krummedal sequence mica schists and quartzites continues northwards to lie on a line with "metamorphic pelitic to psammitic rocks" in Nathorsts Land, which with a decrease in metamorphic grade may be traced into the supracrustals of the Alpefjord region (Zweifel, 1959).

The lower part of the Krummedal supracrustal sequence may correspond to the Basis series of Fränkl (1953) which is a slightly metamorphosed sequence of clastic sediments believed to form the lowest, but almost completely unexposed, deposits in the Caledonian geosyncline in the Alpefjord area. Since the lower part of the Krummedal sequence rests on an infracrustal basement correlation with the Basis series at a similar stratigraphical level would seem reasonable.

The block assemblage in the Charcot Land tillite definitely indicates that the Charcot Land sequence existed at the time of formation of the tillite. Furthermore, it must be stressed that the tillite in Charcot Land rests unconformably on a granite which veins rocks belonging to the Charcot Land sequence. This means that it is likely that the Charcot Land supracrustals had been not only consolidated but also influenced by crustal movements and plutonism before the deposition of the tillite. The correlation of the Charcot Land tillite with either the Eocambrian tillite (Fränkl, 1953) or the supposed earlier tillite from Gaaseland (Wenk, 1961) implies that the above mentioned crustal movements and plutonism must be Precambrian.

The differences between the lithological development of the Charcot Land sequence and the Krummedal sequence, which both rest on a basement, make it unlikely that they could both represent the lowest part of the same 
geosyncline unless Caledonian geosynclinal development was separated into a western eugeosynclinal part, influenced at an early stage by late Precambrian folding, and an eastern miogeosynclinal part.

Rocks belonging to the Charcot Land sequence have earlier been correlated with the marble-chlorite-phyllite series found above the tillite in Gaaseland (Wenk, 1961) and also with a series of marble-chlorite-schists from the Petermann Bjerg region. If this correlation is correct it implies that the Charcot Land sequence starts with one tillite level and is post-dated by another tillite level.

If, however, the tillite in Charcot Land and in Gaaseland represent the same stratigraphical level, then the Charcot Land sequence is older than the lowest part of the supracrustal rocks of Gaaseland. Further investigations will probably clarify these questions, as well as indicate whether the Charcot Land sequence was influenced by pre-Caledonian orogenic movements (Baikalean?).

Ages of $1900 \mathrm{~m} . \mathrm{y}$. and $2300 \mathrm{~m} \cdot \mathrm{y}$. have been obtained on basement rocks below the supracrustals in Gaaseland (Haller and Kulp, 1962) and similar ages might perhaps be expected for the original rocks of the Charcot Land infracrustal complex. Since some reactivation has occurred these ages may be presumed to be minimum estimates. The Flyverfjord infracrustal complex is likkely to be of similar age to the basement in Gaaseland i.e. $>1900 \mathrm{~m} \cdot \mathrm{y}$.

$\mathrm{K} / \mathrm{Ar}$ age determinations on metamorphic rocks from the Scoresby Sund region (Larsen, 1969) indicate that the region was exposed to Caledonian metamorphism about $400 \mathrm{~m} \cdot \mathrm{y}$. ago. The metamorphism of the Krummedal sequence micaschists in Nordvestfjord is dated at $426 \mathrm{~m} . \mathrm{y}$., and intermediate to basic intrusions in the Bjфrneфper area give an age of $435 \mathrm{~m} \cdot \mathrm{y}$. A kyanite-garnet-mica schist from the Føhnfjord-Gaaseland area, probably equivalent to the upper Krummedal sequence, gave 406 $\mathrm{m} . \mathrm{y}$. and $616 \mathrm{~m} \cdot \mathrm{y}$. respectively for muscovite and biotite suggesting that it may have been subjected to both a Caledonian and an earlier (Baikalean ?) plutonic phase since its deposition. 


\section{References}

[ Backlund, H.G.] (1955) Helge Backlund's travels. In Koch, L. Report on the expeditions to Central East Greenland 1926-39. Conducted by Lauge Koch. Part II. Meddr Grønland, Bd. 143, Nr. 2, 303-361.

Fränkl, E. (1951) Die untere Eleonore Bay Formation in Alpefjord. Meddr Grфnland, Bd. 151, Nr. 6 .

Fränkl, E. (1953) Die geologische Karte von Nord. Scoresby Land (NEGrфnland). Meddr Grфnland, Bd. 113, Nr. 6

Haller, J. and Kulp, J.L. (1962) Absolute age determinations in East Greenland. Meddr Grønland, Bd. 171, Nr. 1.

Katz, H.R. (1954) Einige Bemerkungen zur Lithologie und Stratigraphie der Tillitprofile im Gebiet des Kejser Franz Josephs Fjord. . Meddr Gr $\phi$ nland, Bd. 72, Nr. 4.

Katz, H.R. (1961) Late Precambrian to Cambrian stratigraphy in East Greenland. In Raasch, G.O. (edit.) Geology of the Arctic, Vol. 1, 299-328. Toronto U.P.

Larsen, O. (1969) K/Ar age determinations. Rapp. Grфnlands geol. Unders., $\mathrm{Nr} .19,62-67$.

Vogt, P. (1965) Zur Geologie von Südwest-Hinks Land (Ostgrönland $71^{\circ}$ $\left.30^{\prime} \mathrm{N}\right)$. Meddr Grфnland, Bd. 154, Nr. 5 .

Wenk, E. (1956) Alpines und ostgrönländisch-kaledonisches Kristallin, ein tektonisch-petrogenetischer Vergleich. Verh. Naturf. Ges. Basel, Bd. 67, 75-102.

Wenk, E. (1961) On the crystalline basement and the basal part of the pre-Cambrian Eleonora Bay group in the southwestern part of Scoresby Sund. Meddr Grфnland, Bd. 168, Nr. 1.

Zweifel, H. (1959) Geologie und Petrographie von Nathorsts Land (NEGrönland). Meddr Grфnland, Bd. 160, Nr. 3 . 